\title{
Analisis Pengaruh Profitabilitas Dan Kebijakan Dividen Terhadap Nilai Perusahaan Dengan Kapitalisasi Pasar Sebagai Variabel Moderasi (Studi Pada Perusahaan yang Tercatat di Indeks JII70 Periode 2017-2019)
}

\author{
Achmad Haris Setiawan ${ }^{1 *}$, Muhammad Nanang Choiruddin² \\ Jurusan Manajemen, Fakultas Ekonomi, UIN Maulana Malik Ibrahim Malang \\ Jln Gajayana No.50, Dinoyo, Kota Malang, 65144, Indonesia
}

\begin{abstract}
This study aims to find the effect of profitability and dividend policy on firm value with market capitalization as a moderating variable for companies listed on the JII70 Index for the 2017-2019 period. This research is a quantitative research type with a sample population of 104 companies listed in the JII70 Index listed on the Indonesia Stock Exchange in the 2017-2019 period. Furthermore, purposive sampling was carried out to obtain 34 companies that fit the criteria. The results obtained in this study indicate that there is a significant influence between profitability and market capitalization on firm value, only dividend policy has no significant effect on firm value. Meanwhile, the MRA test shows that market capitalization is not able to partially moderate the relationship between profitability and dividend policy on firm value.
\end{abstract}

Keywords: Profitability, Dividend Policy, Firm Value, Market Capitalization

Paper type: Research Paper

*Corresponding author: achmdharis@gmail.com

Received: 03 Maret 2021, ; Accepted: 17 Juni 2021; Published: 25 Juni 2021

Cite this document: Setiawan, A.H \& Choiruddin, M.N (2021). Analisis Pengaruh Profitabilitas Dan Kebijakan Dividen Terhadap Nilai Perusahaan Dengan Kapitalisasi Pasar Sebagai Variabel Moderasi (Studi Pada Perusahaan yang Tercatat di Indeks JII70 Periode 2017-2019). BISEI: Jurnal Bisnis dan Ekonomi Islam, 6 (1), 26-37.

Abstrak: Penelitian ini bertujuan untuk mencari pengaruh antara profitabilitas dan kebijakan dividen terhadap nilai perusahaan dengan kapitalisasi pasar sebagai variabel moderasi pada perusahaan yang tercatat di Indeks JII70 periode 20172019. Penelitian ini berjenis penelitian kuantitatif dengan populasi sampel berjumlah 104 perusahaan yang tercatat dalam Indeks JII70 yang terdaftar di Bursa Efek Indonesia pada periode 2017-2019. Selanjutnya dilakukan purposive sampling untuk mendapatkan 34 perusahaan yang sesuai kriteria. Hasil yang didapatkan dalam penelitian ini menunjukkan bahwa ada pengaruh secara signifikan antara profitabilitas dan

Copyright (C 2021, BISEI: Jurnal Bisnis dan Ekonomi Islam http://ejournal.unhasy.ac.id/index.php/bisei 
Achmad Haris Setiawan, Muhammad Nanang Choiruddin: Analisis Pengaruh Profitabilitas Dan Kebijakan Dividen Terhadap Nilai Perusahaan Dengan Kapitalisasi Pasar Sebagai Variabel Moderasi (Studi Pada Perusahaan yang Tercatat di Indeks JII70 Periode 2017-2019)

kapitalisasi pasar terhadap nilai perusahaan, hanya kebijakan dividen yang tidak berpengaruh signifikan terhadap nilai perusahaan. sementara itu pengujian MRA menunjukkan bahwa kapitalisasi pasar tidak mampu memoderasi hubungan profitabilitas dan kebijakan dividen terhadap nilai perusahaan secara parsial.

Kata kunci: Profitabilitas, Kebijakan Dividen, Nilai perusahaan,Kapitalisasi Pasar

\section{Pendahuluan}

Saat ini berinvestasi dipasar modal mulai banyak diminati oleh berbagai kalangan masyarakat, khususnya generasi para generasi milenial. Hal ini didukung oleh pemerintah melalui Bursa Efek Indonesia dalam mengenalkan dunia investasi pada masyarakat melalui kampanye Yuk Nabung Saham yang dimulai pada tahun 2015. Kampanye ini adalah strategi BEI dalam mengajak masyarakat menjadi calon lnvestor agar mengenal dan mau berinvestasi dengan membeli saham dipasar modal secara rutim dan berkala. Meningkatnya minat investasi masyarakat masyarakat terhadap instrument saham juga tercermin dalam iklim perekonomian Indonesia yang sangat baik untuk berinvestasi. Hal ini dapat dibuktikan dalam data pergerakan indeks IHSG selama jangka 10 tahun kebelakang yang memiliki tren jangka panjang bullish. Selain itu adanya perkembangan ilmu tentang pasar modal serta kemajuan dibidang teknologi dan sistem informasi membuat masyarakat dapat dengan gampang dan cepat dalam memperoleh lnformasi dan belajar saham

\section{Gambar 1}

\section{Kinerja JII70 periode 2009-2019}

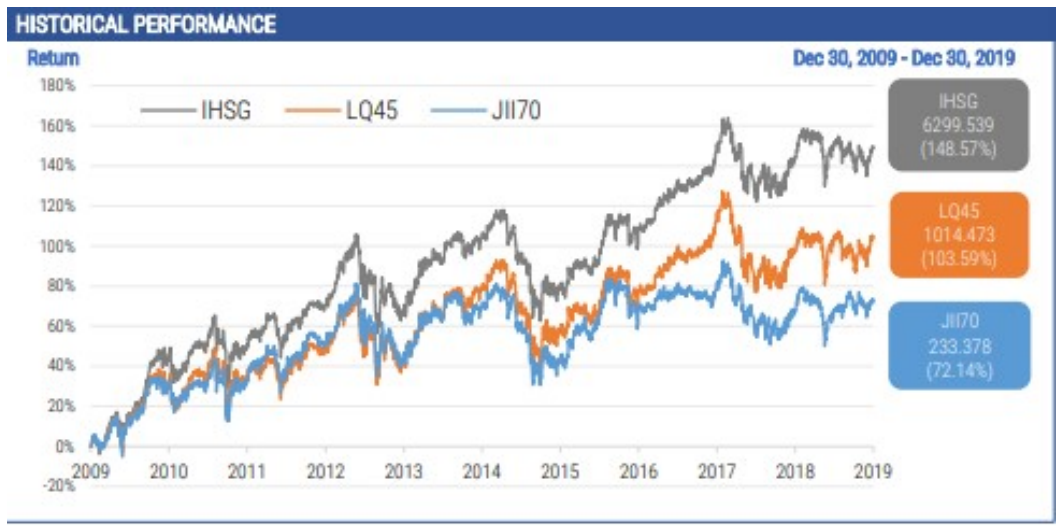

Sumber : Bursa Efek Indonesia

Uniknya disini justru indeks JII70 yang merupakan indeks untuk sahamsaham syariah terbaik justru performanya dibawah indeks-indeks konvensional, bukankah ketika perusahaan sudah disaring seperti pendapatan non halalnya tidak boleh lebih dari 10\% seharusnya hal ini mampu meningkatkan performa perusahaan karena dapat meningkatkan pendapatan dari kegiatan operasional utama perusahaannya, tapi justru kenyataannya sebaliknya, mungkinkah ada faktor-faktor lain mampu menyebabkan nilai perusahaan vang 
berada di lndeks JII70 ini menjadi lebih rendah dengan nilai perusahaan di Indeks seperti IHSG dan LQ45. Sangat menarik untuk diteliti dan dibuktikan, berdasarkan ha1 ini peneliti tertarik untuk mencari tahu beberapa faktpr-faktor yang mempenggaruhi nilai saham di Indeks JII70 ini.

Weston \& Copeland, (1997) menjelaskan bahwa nilai perusahaan dapat diukur dengan melalui beberapa Indikatr seperti Price Earning Ratio, Price to Book Value dan Tobin'sQ. Pada penelitian ini pene1iti akan mengunakan variabe1 Book Value, Nilai perusahan dapat dihitung memakai nilai buku (book value) perusahaan yang merupakan nilai yang menggambarkan ekuitas dibanding dengan saham yang beredar, sehingga dengan nilai buku dianggap sebagai salah satu metode yang digunakan calon investor dalam mengidentifikasi saham yang harganya wajar (undervalue) dan mahal (overvalue). Karena sebagai investor mereka harus bisa memilih perusahaan dengan harga yang layak untuk dibeli oleh calon investor sehingga ia mampu untuk mambayarnnya.( Fuad \& Munir,2006 ).

Ada beberapa beberapa faktor yang dapat mempengaruhi nilai perusahaan, faktor ini didapatkan melalui lingkungan internal maupun ekternal perusahann. Yang dimaksud dengan faktor internal adalah faktor mampu dikendalikan perusahaan melalui kebijakan dan strategi-strategi yang telah disiapkan untuk meningkatkan performa perusahaan. Faktor internal bisa seperti, kinerja perusahaan, keputasan manajemen, sampai sebuah struktur modal perusahan. Adapun beberapa faktor eksternal adalah katalis-katalis luar vang tidak bisa dikendalikan tetapi dapat mempengaruhi kinerja dan performa sebuah perusahaan layaknya inflasi, BI 7days rate, pasar dan faktor 1ain-1ain (Dewi \& Wirasedana, 2018).

lnformasi mengenai kinerja keuangan yang diinterprestasikan dalam indikator keuangan mampu dijadikan bahan bagi investor dalam menentukan strategi dalam investasinya. Dengan membaca laporan keuangan dan menganalisis berbagai informasi didalamnya tentunya akan membuat para investor tidak akan salah dalam membuat keputusan investasi dan menentukan perusahaan yang akan dibeli sahamnya. (Murhadi, 2013).

Informasi mengenai perusahaan sangatlah dibutuhkan calon investor dalam menentukan keputusan sebelum melakukan investasi, oleh karena itu informasi mengenai profitabilitas, kebijakan deviden maupun nilai perusahaan dianggap penting karena dapat mempengaruhi persepsi calon investor terhadap penempatan dana investasinya. Informasi yang diberikan perusahaan akan menjadi sinyal kepada eksternal perusahaan untuk mengetahui perkembangan dan benefit yang didapatkan investor ketika mereka memutuskan menginvestasikan dananya bagi perusahaan. Oleh karena itu dalam Signalling Theory investor memerlukan informasi dari perusahaan sebagai bahan pertimbangan dalam keputusan investasinya

Setiap Investor yang menanamkan dananya untuk berinvestasi pasti ingin mendapatkan imbal hasil dari perusahaan yang dapat menguntungkan bagi dirinya, imbal hasil yang diberikan perusahaan biasanya dalam bentuk deviden. Dividen adalah laba perusahaan yang disiapkan dan akan dbagikan kepada shareholdersnya, besarnya deviden yang dibagikan kepada shareholdersnya biasanya tergantung dengan proporsi saham yang dimiliki masing-masing 
Achmad Haris Setiawan, Muhammad Nanang Choiruddin: Analisis Pengaruh Profitabilitas Dan Kebijakan Dividen Terhadap Nilai Perusahaan Dengan Kapitalisasi Pasar Sebagai Variabel Moderasi (Studi Pada Perusahaan yang Tercatat di Indeks JII70 Periode 2017-2019)

investornya dan biasanya ditentukan dalam persen (Rodoni \& Ali, 2014). Biasanya perusahan yang memiliki profitabillitas yang baik akan membagikan devidennya kepada pemegang sahamnya , karena apabila kondisi keuangan perusahaan baik maka tidak ada alasan bagi perusahan untuk tidak membagikan devidennya kepada shareholdersnya. Oleh karena itu penting sekali bagi perusahaan untuk mempertahanan dan meningkatkan profitabilitasnya agar pembayaran devidennya menjadi stabil

Islam mengajarkan untuk berinvestasi dengan tidak mengesampingkan norma syariah, karena dalam berinvestasi sebagai umat islam diwajibkan untuk berniat tidak hamya mandapatkan keuntungan semara akan tetapi juga berusaha untuk mendapatkan berkah dalam berinvestasi sekaligus adalah hakikat pada ilmu serta ama1. O1eh karenanya, lnvestasi itu harus benar-benar dianjurkun bagi umat islam. Sebagaimana dalam Al Qur'an surat Al Hasyr ayat 18 yang artinya"Hai orang-orang yang beriman, bertakwalah kepada Allah dan hendaklah setiap diri memerhatikan apa yang telah diperbuatnya untuk hari esok (akhirat), dan bertakwalah kepada Allah, sesungguhnya Allah Maha Mengetahui apa yang kamu kerjakan."

Ayat diatas dapat ditafsirkan bahwa setiap ingin melakukan hal untuk di analisa terlebih dahulu sebelum melakukannya, karena hal seperti itu akan dipertangungjawabkan baik didunia maupun diakhirat, termasuk ketika ingin berinvestasi, harus dianalisa dengan baik, karena apapun yang terjadi didalam portofolio, maka yang bertanggung jawab adalah diri sendiri.

Berdasarkan hasil penelitian dari Putra \& Lestari (2016) menemukan bahwa nilai perusahaan dapat dipengaruhi oleh kinerja perusahaan yang diukur melalui rasio profitabilitas. Indikator ini merupakan indikator yang dapat menghitung efektivitas kemampuan manajemen perusahan dalam mengelola dana dan sumber pembiayaan yang ada dalam perusahaan untuk akhirnya dapat membuat perusahaan mampu menghasilkan laba secara konsisten.

Ada faktor-faktor yang dapat mempenggaruhi nilai perusahan antara 1ain kepemilikan saham karyawan, kebijakaan utang, serta kebijakan deviden (Hermuningsih, 2009). Cara dalam meningkatkan nilai perusahaan tidak hanya dilakukan dengan meningkatkan profitabilitas, ada faktor lain yang mampu mempengaruji nilai perusahan. Salah satunya adalah kebijakan deviden, karena deviden dapat memberikan informasi yang baik mengenai manajemen perusahaan kepada para investornya. Kebijakan deviden yang saling menguntungkan pihak stakeholders perusahaan baik manajemen maupun pemegang sahamnya

Menurut Miller \& Modigliani (2001) dengan Irrelevance theory-nya yang mengungkapkan jika nilai perusahaan dapat dipengaruhi oleh kinerja perusahan da1 am menghasilkan keuntungan/1aba dan mengelola risiko usahanya. Artinya laba ditahan yang dibagikan melalui deviden tidak ada hubungannya dengan besarnya nilai perusahaaan. Hal ini diperkuat dengan beberapa penelitian terdahulu Fendyka L.I (2017) dari penelitian yang mereka lakukan ditemukan bahwa Divident Payout Ratio tidak bepengaruh tehadap nilai perusahaan. Akan tetapi hasil itu berbeda drngan yang dipaparkan oleh Gordon \& Litner dalam teori The Bird ln The Hand yang mengungkapkan bahwaa sebenarnya lnvestor lebih menyenangi deviden daripada dengan capital gain sebab dividen memiliki 
sebuah risiko 1ebih rendah dan safety daripada capital gain dimasa depan yang belum pasti. Pernyataan teori ini diperkuat dengan peneIitian terdahulu yang diIakukan oIeh S.A Rochmah (2017), Putra \& Lestari (2016).

Dalam penelitian saat ini peneliti mencoba mengunkap alasan dibalik underperformnya nilai perusahaan diindeks JII70, indeks JII70 sendiri merupakan indeks saham syariah 70 saham yang memiliki likuditas tertinggi di Bursa Efek Indonesia. Dimana saham di lndeks ini disesuaikan selama dua kali setahun. Dalam penelitian kali ini, peneliti mencoba untuk memberikan suatu kebaharuan dengan menambahkan indikator lain, yaitu kapitalisasi pasar untuk memoderasi pengaruh kinerja keuangan dan kebijakan deviden terhadap nilai perusahan. Kapitalisasi pasar sendiri merupakan nilai pasar dari saham yang diterbitkan suatu perusahaan, kapitalisasi pasar ini didapatkan dengan cara mengalikan jumlah saham yang beredar dengan harga saham penutupan. Dalam hal ini dapat dilihat bahwa besar atau tidaknya perusahaan didalam pasar saham bisa dinilai dari kapitalisasi pasar, yang artinya semakin tinggi kapitalisasi pasar akan membuat nilai perusahaan akan semakin tinggi dimata calon investor (Rifqiawan, 2015)

Berdasarkan latar belakang saham-saham syariah yang under perform padahal sudah ada klasifikasi-klasifikasi yang seharusnya memperkuat kinerjanya seperti pendapatan halalnya yang harus $90 \%$ dari pendapatannya dan utang berbunga yang tidak boleh lebih dari $45 \%$ dari modal perusahaan, kenapa malah membuah saham-saham syariah ini memiliki kinerja dibawah perusahaan konvensional. Hal ini membuat peneliti tertarik untuk melakukan penellitian dengan judul Analisis Pengaruh Profitabilitas dan Kebijakan Deviden Terhadap Nilai Perusahaan dengan Kapitalisasi Pasar sebagai Variabel Moderasi (Studi Pada Perusahaan yang Tercatat di Indeks JII70 Periode 2017-2019).

\section{Metode Penelitian}

Jenis penelitian yang digunakan adalah penelitian kauntitatif dengan mengunakan 2 variabe1 yang memiliki hubungan variabe1 terikat dan hubungan moderating, penelitian ini juga bisa sebut dengan penelitian kausalitas dimana mempunyai keterikatan antara 2 variabe1 atau 1ebih. Penelitian ini berlokasi pada Galeri Investasi Syariah UIN Maulana Malik Ibrahim Malang dimana data didapatkan dari website lndonesia Stock Echange. Penelitian dilakukan dengan pengambilan data perusahan yang termasuk da1am indeks Jakarta lslamic lndex 70, terakhir data diambil dari situs internet: (www.idx.co.id).

Populasi dan Sampel

Metode dalam menentukan sampel pada penelitian ini mengunakan Metode Purposive Sampling adalah dalam menentukan sampel dengnn mempertimbangkan beberapa kriterianya. (Jogiyanto,2013). Adapun adanya kriteria yang ditentukan peneliti adalah : :

1. Perusahaan yang secara konsisten masuk secara berturut-turut didalam Indeks Jakarta Islamic Indeks (JII) selama periode 2017-2019.

2. Perusahaan Indeks Jakarta Islamic Index yang mampu mendapatkan laba secara konsiststen secara berturut-turut se1 ama periode 2017-2019.

Copyright (C) 2021, BISEI: Jurnal Bisnis dan Ekonomi Islam http://ejournal.unhasy.ac.id/index.php/bisei 
Achmad Haris Setiawan, Muhammad Nanang Choiruddin: Analisis Pengaruh Profitabilitas Dan Kebijakan Dividen Terhadap Nilai Perusahaan Dengan Kapitalisasi Pasar Sebagai Variabel Moderasi (Studi Pada Perusahaan yang Tercatat di Indeks JII70 Periode 2017-2019)

3. Perusahaan Indeks Jakarta Islamic Index yang membagikan dividen konsiststen secara berturut-turut selama periode 2017-2019 Perusahaan Indeks Jakarta Islamic Index yang memiliki daya yang tersedia lengkap untuk diteliti selama periode 20172019

Adapaun tabel perusahaan Indeks JII70 dengan metode pusposive sampling pada Indeks JII ditabelkan dengan kriteria sampel penelitian sebagai berikut :

Tabel 1

Kriteria Sampel Emiten yang Terdaftar di Indeks JII70

Periode 2017-2019

\begin{tabular}{|c|l|c|}
\hline No & Klasifikasi & Jumlah \\
\hline 1 & Emiten yang konsisten masuk indeks JII70 & 48 \\
\hline 2 & Emiten yang tidak konsisten laba & $(8)$ \\
\hline 3 & Emiten yang tidak konsisten bagi dividen & $(6)$ \\
\hline 4 & Emiten yang memenuhi kriteria penelitian & 34 \\
\hline
\end{tabular}

Sumber : Data diolah peneliti

Hipotesis Penelitian :

H1 : Profitabilitas berpengaruh signifikan positif terhadap nil ai perusahaan

H2 : Kebijakan Dividen berpengaruh signifikan positif terhadap nilai perusahaan

H3 : Kapitalisasi Pasar berpengaruh signifikan positif terhadap nilai perusahaan

H4: Kapitalisasi Pasar dapat memoderasi pengaruh antara Profitabilitas dan

Kebijakan Dividen Terhadap Nilai Perusahaan

Teknik Analisis Data

Penelitian kali in memakai pengujian dengan analisis dengan ditambah variabel moderasi (MRA). Analisis ini menggunakan metode khusus regresi linear berganda dimana didalamnya mempunyai hubungan yang dihasilkan dari penelitian dua atau 1ebih variabe1 independe (Ghozali, 2013)

\section{Hasil dan Pembahasan}

Perkembangan pasar modal Indonesia setiap tahunnya mengalami peningkatan, begitu juga dengan perkembangan pasar modal syariahnya. Pada penelitian ini berobjek pada perusahaan di Indeks Jakarta Islamic Index 70, yang merupakan Indeks saham-saham syariah paling likuid dan yang memiliki kriteria yang sesuai dengan prinsip syariah. Dalam indeks JII70 setiap perusahaan yang masuk akan di evaluasi setiap 6 bulan sekali yakni ketika bulan mei dan bulan november. Dimana pemilihan saham dalam indeks ini setiap semester dipilih langsung oleh OJK dengan dibantu oleh Dewan Syariah Nasional.

Berdasarkan hasil statistik deskriptif menunjukkan bahwa variabel profitabilitas yang diukur dengan indikator ROA memiliki nilai minimum senilai 0,66 dan nilai maksimum senilai 46,52 dengan nilai mean (rata-rata) sebesar 10,0534 dan nilai standar deviasi sebesar 8,28461. Selanjutnya variabel Kebijakan dividen yang diukur dengan indikator DPR yang memiliki nilai minimum senilai 5,00 dan nilai maksimum senilai 210,00 dengan nilai mean (rata-rata) sebesar 
48,3712 dan nilai standar deviasi sebesar 36,45422. Kemudian ada variabel dependen yaitu nilai perusahaan yang diukur dengan indikator PBV yang memiliki nilai minimum senilai 0,56 dan nilai maksimum senilai 82,44 dengan nilai mean (rata-rata) sebesar 4,4369 dan nilai standar deviasi sebesar 10,76296. Dan terakhir variabel moderasi dengan variabel kapitalisasi pasar yang memiliki nilai minimum senilai 3300 dan nilai maksimum senilai 447600 dengan nilai mean (rata-rata) sebesar 64804.90 dan nilai standar deviasi sebesar 100280,898.

\section{Uji Regresi}

Pengujian ini dilakukan untuk melihat seberapa besar variabel bebas mampu menjelaskan tentang variabel terikatnya. Dimana nilai determinasi dijelaskan dengan nilai adjusted $R$ square.

Tabel 2

\section{Hasil Uji R Square}

Model Summary

\begin{tabular}{|l|l|r|r|r|}
\hline Model & $\mathrm{R}$ & $\mathrm{R}$ Square & $\begin{array}{c}\text { Adjusted R } \\
\text { Square }\end{array}$ & $\begin{array}{c}\text { Std. Error of } \\
\text { the Estimate }\end{array}$ \\
\hline 1 & $.797^{\mathrm{a}}$ & .636 & .622 & 1.09276 \\
\hline
\end{tabular}

a. Predictors: (Constant), Kapitalisasi Pasar, Profitabilitas, Kebijakan Dividen

Tabel diatas menunjukkan bahwa pada bagian R-square terlihat bahwa nilainya adalah 0,636 yang artinya $63 \%$ variabel nilai perusahaan mampu dijelaskan dengan variabel profitabilitas (ROA), kebijakan dividen(DPR) dan kapitalisasi pasar dan sisanya hanya 37\% yang diwakili oleh variabel-variabel yang lainnya.

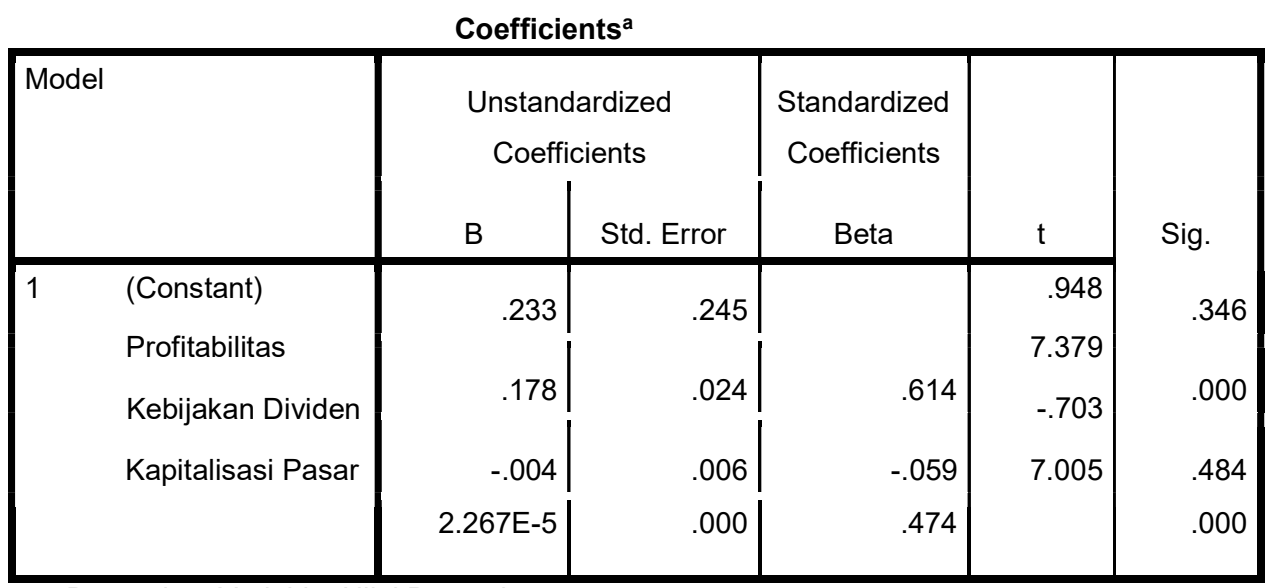

a. Dependent Variable: Nilai Perusahaan

\section{Profitabilitas Terhadap Nilai Perusahaan}

Hasil pengujian menunjukkan bahwa koefisien determinan profitabilitas menunjukkan bahwa nilai 0,223 dan nilai t 7,379 dengan hasil signifikansi sebesar 0,00 atau nilainya nilainya lebih kecil dari 0,05 yang artinya profitabilitas mempunyai pengaruh positif dan signifikan terhadap nilai perusahaan. Rasio 
Achmad Haris Setiawan, Muhammad Nanang Choiruddin: Analisis 33

Pengaruh Profitabilitas Dan Kebijakan Dividen Terhadap Nilai Perusahaan Dengan Kapitalisasi Pasar Sebagai Variabel Moderasi (Studi Pada Perusahaan yang Tercatat di Indeks JII70 Periode 2017-2019)

profitabilitas yang digunakan pada penelitian ini adalah Return On Asset (ROA) yang mampu menjelaskan kemampuan perusahaan dalam menghasilkan laba dengan menggunakan total aktiva yang dimilikinya (Harrison Jr. 2011), sehingga terkadang ROA digunakan investor dalam menilai perusahaan apakah efisien ataukah tidak dalam mengelola assetnya. Hal ini terjadi apabila semakin tinggi kemampuan perusahaan dalam menghasilkan laba tentunya semakin efisien pula perputaran asetnya sehingga margin yang didapatkan perusahaan ikut tinggi juga. oleh karena itu tugas manajemen perusahaan untuk meningkatkan kinerjanya dengan itu nilai perusahaan akan baik dan membuat investor tertarik untuk berinvestasi di perusahaannya Adapun hasil penelitian ini sejalan dengan hasil penelitina yang telah dilakukan oleh Rosyidah Ulfa (2018), Faudia Forma Y (2018), R.A Rifqiawan (2015)

\section{Kebijakan Dividen Terhadap Nilai Perusahaan}

Hasil pengujian selanjutnya menunjukkan bahwa koefisien determinan variabel kebijakan dividen menunjukkan bahwa nilai 0,173 dan nilai t 0,703 dengan hasil signifikansi sebesar 0,484 atau nilainya nilainya lebih besar dari 0,05 yang artinya kebijakan dividen mempunyai pengaruh negatif dan signifikan terhadap nilai perusahaan. selanjutnya hasil penelitian menunjukkan bahwa kebijakan dividen berpengaruh signifikan negatif terhadap nilai perusahaan yang tercatat di Indeks JII70 periode 2017-2019. Hal ini sesuai dengan Menurut Miller \& Modigliani (2001) dengan Irrelevance theory-nya yang menyatakan bahwa nilai perusahaan hanya dipengaruhi oleh kinerja perusahaan dalam menghasilkan keuntungan/laba dan mengelola risiko bisnisnya. Dengan kata lain laba ditahan yang dibagikan melalui deviden tidak ada hubungannya dengan besarnya nilai perusahaaan. Disisi lain investor lebih menyukai capital gain karena bisa didapatkan dalam waktu yang singkat jika dibandingkan dividen yang dianggap lebih lama menunggunya. Penelitian ini sesuai dengan penelitian yang dilakukan oleh Fendyka (2017) yang menyatakan bahwa kebijakan dividen berpengaruh negatih terhadap nilai perusahaan dikarenakan perusahaan yang sudah besar cenderung untuk memutarkan kembali hasil keuntungannya untuk kegiatan operasionalnya sehingga perusahaan bisa mempercepat pertumbuhan perusahaan.

\section{Kapitalisasi Pasar Terhadap Nilai Perusahaan}

Hasil pengujian selanjutnya menunjukkan bahwa koefisien determinan variabel kebijakan dividen menunjukkan bahwa nilai 2,26 dan nilai t 7,005 dengan hasil signifikansi sebesar 0,00 atau nilainya nilainya lebih kecil dari 0,05 yang artinya kapitalisasi pasar mempunyai pengaruh positif dan signifikan terhadap nilai perusahaan. Menurut Tandelillin, (2001) nilai pasar suatu perusahaan haruslah mencerminkan nilai bukunya. Kapitalisasi pasar atau sering disebut dengan marketcap adalah nilai total perusahaan yang diperdagangkan dipasar sekunder (bursa saham). Logika sederhananya adalah apabila investor ingin membeli seluruh saham sebuah perusahaan yang ada di bursa, dana yang dibutuhkan adalah senilai dengan marketcap perusahaan itu dibursa saham. Hasil penelitian ini menunjukkan bahwa kapitalisasi pasar berpengaruh positif terhadap nilai perusahaaan. Hal ini sesuai dengan penelitian yang dilakukan Oleh 
Rifqiawan (2015) yang menyatakan bahwa besar atau tidaknya perusahaan didalam pasar saham bisa dinilai dari kapitalisasi pasar, yang artinya semakin tinggi kapitalisasi pasar akan membuat nilai perusahaan akan semakin tinggi dimata calon investor.

\section{Kapitalisasi Pasar Memoderasi Hubungan Antara Profitabilitas Terhadap Nilai Perusahaan}

Tabel 4

\section{Uji Moderasi tahap 1}

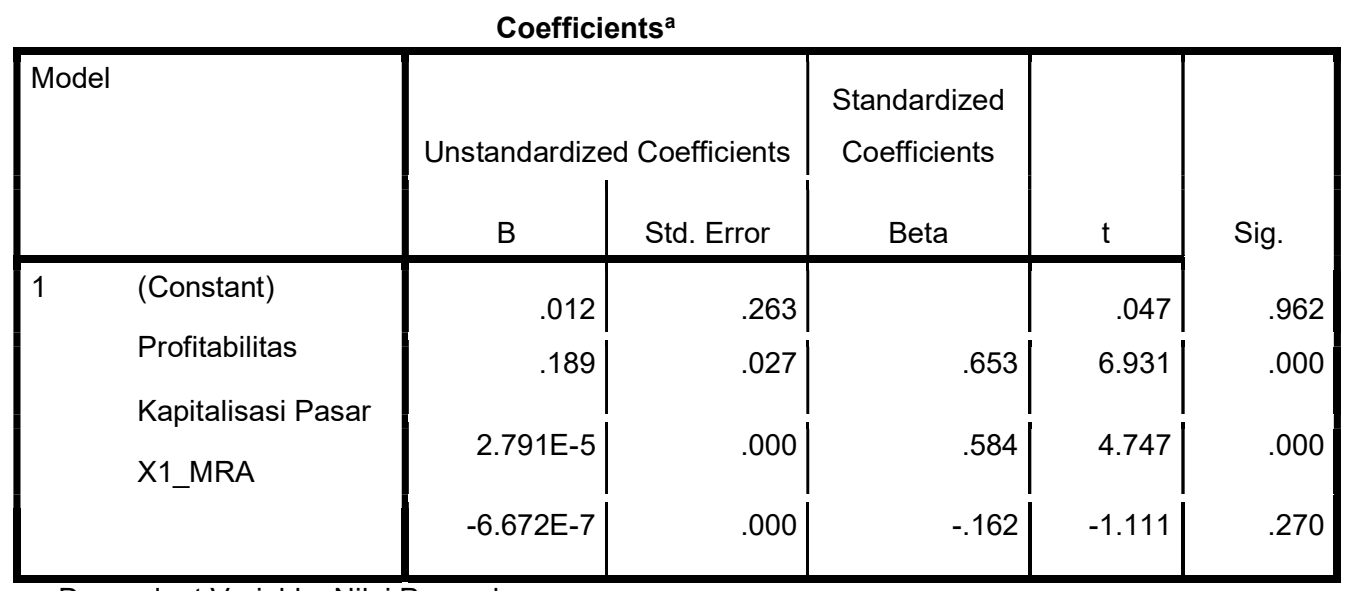

a. Dependent Variable: Nilai Perusahaan

Dari hasil uji MRA pada tabel 4 menunjukkan hasil 0,270 yang memiliki nilai lebih dari 0,005 yang artinya kapitalisasi pasar tidak mampu memoderasi hubungan antara profitabilitas terhadap nilai perusahaan sehingga dari hasil uji tersebut diketahui kalau kapitalisasi pasar memperlemah hubungan antara profitabilitas terhadap nilai perusahaan. Hasil penelitian ini menunjukkan bahwa investor tidak hanya melihat informasi dari perusahaan yang terus meningkatkan asetnya saja tapi juga kemampuan perusahaan dalam mengelola asetnya untuk meningkatkan profitabilitasnya. Karena akan percuma apabila aset perusahaan yang tinggi justru membuat margin keuntungan perusahaan semakin kecil yang menunjukkan perusahaan belum mampu mengefesiensi aset yang dimilikinya untuk meyakinkan investor dalam mengivestasikan dananya ke perusahaan, hal ini menyebabkan kapitalisasi perusahaan yang akan terus stagnan dan cenderung turun apabila perusahaan tak mampu menarik investor untuk mendanai perusahaannya. Hal ini sesuai juga dengan penelitian yang dilakukan oleh Aisyah (2012) dan Simarmayarani (2015) dalam Fendyka (2017)

Kapitalisasi Pasar Memoderasi Hubungan Antara Kebijakan Dividen Terhadap Nilai Perusahaan

Tabel 5

Uji Moderasi tahap 2

Copyright (C) 2021, BISEI: Jurnal Bisnis dan Ekonomi Islam

http://ejournal.unhasy.ac.id/index.php/bisei 
Achmad Haris Setiawan, Muhammad Nanang Choiruddin: Analisis 35

Pengaruh Profitabilitas Dan Kebijakan Dividen Terhadap Nilai Perusahaan

Dengan Kapitalisasi Pasar Sebagai Variabel Moderasi (Studi Pada

Perusahaan yang Tercatat di Indeks JII70 Periode 2017-2019)

Coefficients $^{\mathrm{a}}$

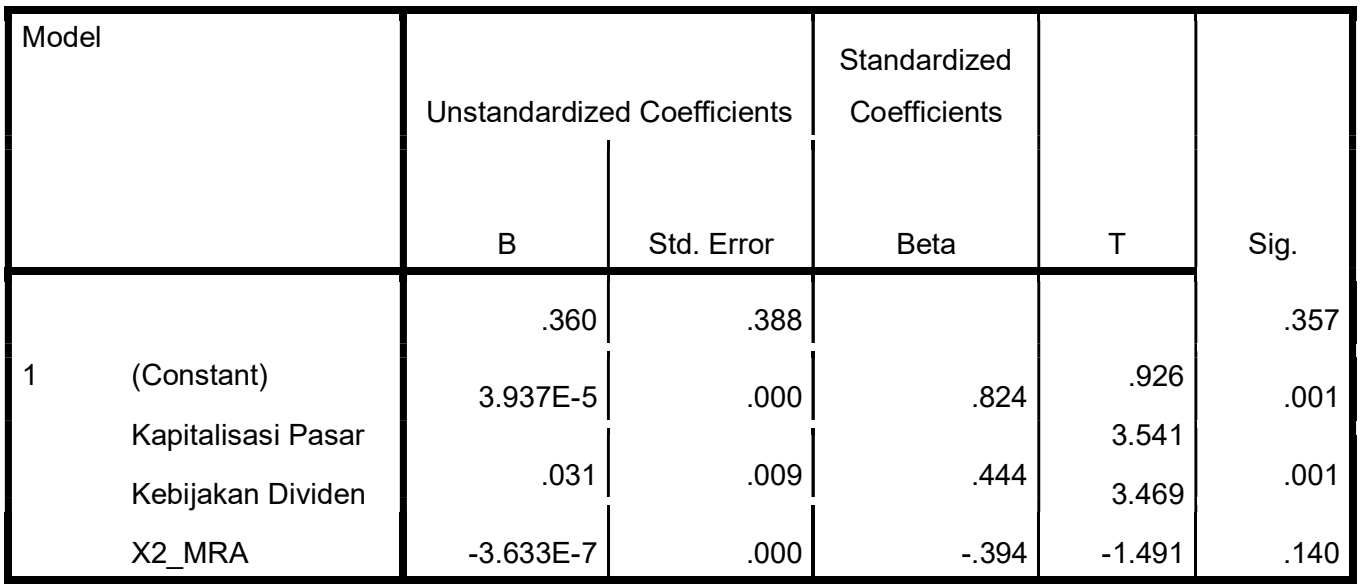

a. Dependent Variable: Nilai Perusahaan

Dari hasil uji MRA pada tabel 5 menunjukkan hasil 0,140 yang memiliki nilai lebih dari 0,005 yang artinya kapitalisasi pasar tidak mampu memoderasi hubungan antara kebijakan terhadap nilai perusahaan sehingga dari hasil uji tersebut diketahui kalau kapitalisasi pasar memperlemah hubungan antara kebijakan dividen terhadap nilai perusahaan. Hal ini sesuai dengan Menurut Miller \& Modigliani (2001) dengan Irrelevance theory-nya yang menyatakan bahwa nilai perusahaan hanya dipengaruhi oleh kinerja perusahaan dalam menghasilkan keuntungan/laba dan mengelola risiko bisnisnya. Dengan kata lain laba ditahan yang dibagikan melalui deviden tidak ada hubungannya dengan besarnya nilai perusahaaan. Penelitian ini sesuai dengan penelitian yang dilakukan oleh Fendyka (2017) yang menyatakan bahwa kebijakan dividen berpengaruh negatih terhadap nilai perusahaan dikarenakan perusahaan yang sudah besar cenderung untuk memutarkan kembali hasil keuntungannya untuk kegiatan operasionalnya sehingga perusahaan bisa mempercepat pertumbuhan perusahaan.

\section{Penutup}

\section{Kesimpulan}

1. Dalam penelitian ini profitabilitas diproyeksikan dalam Return On Asset yang hasil penelitian ini menunjukkan bahwa profitabilitas berpengaruh signifikan positif terhadap nilai perusahaan yang tercatat di Indeks JII70 periode 20172019.

2. Kebijakan Dividen diproyeksikan dalam Dividend Payout Ratio (DPR). Selanjutnya hasil penelitian menunjukkan bahwa kebijakan dividen berpengaruh signifikan negatif terhadap nilai perusahaan yang tercatat di Indeks JII70 periode 2017-2019.

3. Kapitalisasi Pasar atau sering disebut dengan marketcap hasil penelitian menunjukkan bahwa kapitalisasi pasar berpengaruh 
signifikan positif terhadap nilai perusahaan yang tercatat di Indeks JII70 periode 2017-2019.

4. Dalam penelitian ini peneliti mencoba menambahkan variabel moderasi yaitu kapitalisasi pasar. Hasil penelitian ini menunjukkan bahwa kapitalisasi pasar tidak mampu mempderasi hubungan antara profitabilitas terhadap nilai perusahaaan yang tercatat di Indeks JII70 periode 2017-2019.

5. Selain itu peneliti juga menguji hubungan antara kebijakan dividen terhadap nilai perusahaan dengan menambahkan variabel moderasi yaitu kapitalisasi pasar. Hasil penelitian ini menunjukkan bahwa kapitalisasi pasar tidak mampu memoderasi hubungan antara kebijakan dividen terhadap nilai perusahaaan yang tercatat di Indeks JII70 periode 2017-2019.

\section{Referensi}

Al-Qur'an Terjemahan \& Asbabun Nuzul. (2009). Al Malik. Surakarta.CV AlHanan.

Dewi, L.P.U Kartika \& Wirasedana.(2012). Pengaruh Keputusan Investasi,

Keputusan Pendanaan, Kebijakan Deviden dan Tingkat Inflasi Terhadap Nilai Perusahaaan. E-Jurnal Akuntansi Universitas Udatayana 23(2), 813-841.

Fuad, Munir. (2006). Pengantar Bisnis. Jakarta; PT Gramedia Utama. Ghozali, I (2012) Aplikasi Analisis Multivariate dengan Program SPSS.

Semarang : Badan Penerbit Universitas Diponegoro.

Harrison Jr, W, T., Hongren, C,T Thomas, C, W \& Suwardy. T. (2011). Akuntansi Keuangan Internasional Edisi 8 Jilid 2. Jakarta : Erlangga.

Hermuningsih, S., \& Wardani, D. K. (2009). Faktor-faktor yang mempengaruhi nilai perusahaan pada perusahaan yang terdaftar di Bursa Efek Malaysia dan Bursa Efek Indonesia. Jurnal Siasat Bisnis, 13(2).

Murhadi.W.R. (2013). Analisis Laporan Keuangan Proyeksi dan Valuasi Saham. Jakarta: Salemba Empat.

Putra, A. N. D. A., \& Lestari, P. V. (2016). Pengaruh Kebijakan Deviden, Likuiditas, Profitabilitas dan Ukuran Perusahaan Terhadap Nilai Perusahaan. E-Jurnal Manajemen Unud, (7), 4070.

Rifqiawan, R. A. (2015). Pengaruh Profitabilitas dan Kapitalisasi Pasar terhadap Nilai Emiten Jakarta Islamic Index. Economica: Jurnal Ekonomi Islam, 6(2), 21-36. 
Achmad Haris Setiawan, Muhammad Nanang Choiruddin: Analisis Pengaruh Profitabilitas Dan Kebijakan Dividen Terhadap Nilai Perusahaan Dengan Kapitalisasi Pasar Sebagai Variabel Moderasi (Studi Pada Perusahaan yang Tercatat di Indeks JII70 Periode 2017-2019)

Rochmah, S. A., \& Fitria, A. (2017). Pengaruh kinerja keuangan terhadap nilai

perusahaan: kebijakan dividen sebagai variabel moderating. Jurnal Ilmu dan Riset Akuntansi (JIRA), 6(3).

Putra, A. N. D. A., \& Lestari, P. V. (2016). Pengaruh Kebijakan Deviden, Likuiditas, Profitabilitas dan Ukuran Perusahaan Terhadap Nilai Perusahaan. E-Jurnal Manajemen Unud, (7), 4070.

Ulfa, R., \& Asyik, N. F. (2018). Pengaruh Kinerja Keuangan Terhadap Nilai Perusahaan Dengan Good Corporate Governance Sebagai Variabel Moderasi. Jurnal Ilmu dan Riset Akuntansi (JIRA), 7(10).

Weston \& Copeland (1997). Manajemen Keuangan Jilid II. Jakarta :Binarupa Aksara.

www.idx.co.id diakses Oktober 2020. 